\begin{tabular}{|l|l|l||}
\hline \multicolumn{2}{|c|}{ PublisherInfo } \\
\hline \hline PublisherName & $:$ & BioMed Central \\
\hline \hline PublisherLocation & $:$ & London \\
\hline \hline PublisherImprintName & $:$ & BioMed Central \\
\hline \hline
\end{tabular}

\title{
Ventilatory responses to ozone are reduced in immature rats
}

\begin{tabular}{|l|l|l||}
\hline \multicolumn{2}{|c|}{ ArticleInfo } \\
\hline \hline ArticleID & $:$ & 1651 \\
\hline \hline ArticleDOI & $:$ & $10.1186 /$ rr-2001-68585 \\
\hline \hline ArticleCitationID & $:$ & 68585 \\
\hline \hline ArticleSequenceNumber & $:$ & 62 \\
\hline \hline ArticleCategory & $:$ & Paper Report \\
\hline \hline ArticleFirstPage & $:$ & 1 \\
\hline \hline ArticleLastPage & $:$ & 4 \\
\hline \hline & & RegistrationDate $: 2001-9-20$ \\
& $:$ & Received \\
\hline ArticleHistory & & Accepted 2000-7-25 \\
& $:$ 2001-9-20 \\
\hline \hline ArticleCopyright & $:$ & Biomed Central Ltd2001 \\
\hline \hline ArticleGrants & $:$ & \\
\hline \hline \hline ArticleContext & $:$ & 129312211 \\
\hline \hline
\end{tabular}


Jeff Fedan, ${ }^{\text {Aff1 }}$

Corresponding Affiliation: Aff1

Aff1 The Centers for Disease Control and Prevention, Georgia, USA

\section{Keywords}

Inflammation, lung injury, ozone, plethysmograph, rat, respiration

\section{Introduction}

Air quality is a risk factor for the development of asthma. There is currently an upsurge in the incidence of asthma in children and it is consequently of great importance to understand the effects of inhaled pollutants in children. Few studies have attempted to model the effects of ozone early in life.

The degree of lung injury caused by ozone inhalation is a function of the inspired concentration, the duration of the exposure, and the minute ventilation rate. Inhalation of ozone results in a decrease in minute ventilation; this protective response may ameliorate the degree of injury. No previous studies have examined the ventilatory response of immature animals after ozone inhalation; this is the first study to characterize and compare responses of mature and immature rats to inhaled ozone.

\section{Comments}

This important study has identified significant differences in specific minute ventilation between immature and mature rats, and in the effects and susceptibilities to inhaled ozone. At a given level of ambient ozone, immature rats received a five- to six-fold greater dose than mature animals. The dose of ozone used is high ( $2 \mathrm{ppm}, 3 \mathrm{~h}$ ), perhaps distracting from a direct relationship of the findings to air pollution. The age-dependent differences may pertain to the effects of environmental levels of the gas, which, if studied along with alterations in airway reactivity, could provide additional insights into the effects of ozone during development.

\section{Methods}


After acclimation to nose-only-exposure plethysmographs, ozone ( $2 \mathrm{ppm}$ for $3 \mathrm{~h}$ ) or air was delivered while measuring chamber pressure changes

Software was used to compute (on a breath by breath basis) minute ventilation, tidal volume, inspiratory time, and expiratory time and rate

In separate animals bronchoalveolar lavage (BAL) fluid was collected $0 \mathrm{~h}$ or $4 \mathrm{~h}$ after exposure for measurement of protein, prostaglandin $\mathrm{E}_{2}\left(\mathrm{PGE}_{2}\right)$ and cell count (neutrophils, macrophages, epithelial cells)

\section{Results}

A comparison was made of the effects of treatment with 2 ppm ozone on minute ventilation of rats 2 , 4, 6, 8 and 12 weeks old. Before exposure, immature animals had a greater minute ventilation and tidal volume than mature animals (after normalization for body weight). Mature rats ( 8 and 12 weeks) responded with a decrease (50-60\%) in minute ventilation due to a fall in tidal volume. No decrease in minute volume occurred in immature rats ( 2 and 4 weeks) in response to ozone and 6-week-old animals were intermediate in their minute ventilation response. Protein concentration of BAL medium was elevated after a delay ( $4 \mathrm{~h}$ post-exposure) to a greater degree in 2-week-old rats compared to 8-week-old rats. PGE2 levels in BAL were elevated in 2-week-old rats; this response was not seen in adult animals. Neutrophils and epithelial cells in the BAL fluid were elevated in 4-week-old rats; this response was absent in 2-week-old animals.

\section{Additional information}

American Thoracic Society: Am J Respir Crit Care Med 1996, 153:3-50.

Leikauf et al, Environ Health Persp 1995, 103:91-95.

\section{References}


1. Shore SA, Abraham JH, Schwartzman IN, Krishna Murthy GG, Laporte JD: Ventilatory responses to ozone are reduced in immature rats. J Appl Physiol. 2000, 88: 2023-2030.

This PDF file was created after publication. 